\title{
Marinobacter psychrophilus sp. nov., a psychrophilic bacterium isolated from the Arctic
}

Correspondence

Yong Yu

yuyong@pric.gov.cn

\author{
De-Chao Zhang, ${ }^{1}$ Hui-Rong Li, ${ }^{2}$ Yu-Hua Xin, ${ }^{3}$ Zhen-Ming Chi, ${ }^{1}$ \\ Pei-Jin $\mathrm{Zhou}^{3}$ and Yong $\mathrm{Yu}^{2}$
}

\author{
${ }^{1}$ UNESCO Chinese Center of Marine Biotechnology, Ocean University of China, Qingdao 266003 \\ PR China \\ ${ }^{2}$ SOA Key Laboratory for Polar Science, Polar Research Institute of China, Shanghai 200136, \\ PR China \\ ${ }^{3}$ China General Microbiological Culture Collection Center and State Key Laboratory of Microbial \\ Resources, Institute of Microbiology, Chinese Academy of Sciences, Beijing 100101, PR China
}

\begin{abstract}
Strain $20041^{\top}$ was isolated from sea-ice of the Canadian Basin ( $\left.78^{\circ} 23^{\prime} 1^{\prime \prime} 4^{\prime} \mathrm{N} 149^{\circ} 06^{\prime} 55^{\prime \prime} \mathrm{W}\right)$. Phylogenetic analysis based on 16S rRNA gene homology showed that strain $20041^{\top}$ was related to members of the genus Marinobacter and had highest 16S rRNA gene sequence similarity with the type strain of Marinobacter maritimus. Cells were Gram-negative, rod-shaped, psychrophilic and motile. The temperature range for growth was $0-22{ }^{\circ} \mathrm{C}$, with optimum growth occurring at $16-18{ }^{\circ} \mathrm{C}$ and at approximately $\mathrm{pH} 6.0-9.0$. Strain $20041^{\top}$ had ubiquinone-9 as the major respiratory quinone and iso- $\mathrm{C}_{15: 0} 2 \mathrm{OH}$ and/or $\mathrm{C}_{16: 1} \omega 7 c, \mathrm{C}_{16: 0}, \mathrm{C}_{18: 1} \omega 9 c$ and $\mathrm{C}_{12: 0}$ $3 \mathrm{OH}$ as major fatty acids. The genomic DNA G+C content was $55.4 \mathrm{~mol} \%$. On the basis of the phenotypic characteristics, phylogenetic analysis and DNA-DNA relatedness data, strain $20041^{\top}$ is considered to represent a novel species, for which the name Marinobacter psychrophilus sp. nov. is proposed. The type strain is $20041^{\top}\left(=\mathrm{CGMCC} 1.6499^{\top}=\mathrm{JCM}\right.$ $\left.14643^{T}\right)$.
\end{abstract}

The genus Marinobacter was proposed by Gauthier et al. (1992) to accommodate Gram-negative, aerobic, moderately halophilic gammaproteobacteria that used several hydrocarbons as sole sources of carbon and energy. Recently, many further species, for example Marinobacter algicola (Green et al., 2006), Marinobacter vinifirmus (Liebgott et al., 2006), Marinobacter koreensis (Kim et al., 2006), Marinobacter gudaonensis ( $\mathrm{Gu}$ et al., 2007), Marinobacter salsuginis (Antunes et al., 2007), Marinobacter segnicrescens (Guo et al., 2007) and Marinobacter salicampi (Yoon et al., 2007), have been added to the genus Marinobacter, which at the time of writing includes 18 species. In this study, a psychrophilic bacterial strain, $20041^{\mathrm{T}}$, isolated from sea-ice samples from the Arctic has been identified as representing a novel species of the genus Marinobacter within the Gammaproteobacteria.

Strain $20041^{\mathrm{T}}$ was isolated from sea-ice samples collected off the Canadian Basin of the Arctic Ocean ( $78^{\circ} 23^{\prime} 14^{\prime \prime} \mathrm{N}$

The GenBank/EMBL/DDBJ accession number for the 16S rRNA gene sequence of Marinobacter psychrophilus $20041^{\top}$ is D0.060402.

The fatty acid profiles of strain $20041^{\top}$ and recognized Marinobacter species are available as supplementary material with the online version of this paper. $\left.149^{\circ} 06^{\prime} 55^{\prime \prime} \mathrm{W}\right)$, collected using a MARK II ice auger during the Second Chinese National Arctic Research Expedition cruise of the USCGC icebreaker Xue Long into the Canada Basin in August 2003. Sea-ice samples were cut carefully into $10-20 \mathrm{~cm}$ sections using a sterile saw and placed in sterile plastic bottles to be melted at $4{ }^{\circ} \mathrm{C}$. The isolation and purification of bacterial strains was done as described elsewhere (Zhang et al., 2006). Strain $20041^{\mathrm{T}}$ was stored at $-80{ }^{\circ} \mathrm{C}$ in marine 2216 broth (MB; Difco) supplemented with $30 \%(\mathrm{v} / \mathrm{v})$ glycerol. Marinobacter maritimus JCM $12521^{\mathrm{T}}$ was obtained from the JCM. The culture was routinely grown on marine 2216 agar (MA) or in $\mathrm{MB}$ at $22{ }^{\circ} \mathrm{C}$ and used as a reference strain.

DNA was extracted and purified as described by Sambrook et al. (1989). The $16 \mathrm{~S}$ rRNA gene was amplified by PCR with universal primers (Zhang et al., 2006). Purified PCR product was ligated into pMD 18-T (TaKaRa Bio) and cloned according to the manufacturer's instructions. Sequencing reactions were carried out using the ABI BigDye 3.1 Sequencing kit (Applied BioSystems) and an automated DNA sequencer (model ABI3730; Applied BioSystems). The 16S rRNA gene sequence of strain $20041^{\mathrm{T}}$ was submitted to GenBank and EMBL to search for similar sequences using the BLAST algorithm. The phylogenetic tree was constructed using Kimura two-parameter and pairwise-deletion model 
analyses implemented in the program MEGA version 3.0 (Kumar et al., 2004). The resultant tree topologies were evaluated by bootstrap analysis based on 1000 replicates. The nearly complete $16 \mathrm{~S}$ rRNA gene of strain $20041^{\mathrm{T}}$ (1506 bp) was PCR-amplified and sequenced. Phylogenetic analysis (Fig. 1) showed that strain $20041^{\mathrm{T}}$ was grouped with the members of the genus Marinobacter, and formed a distinct cluster with Marinobacter maritimus CK $47^{\mathrm{T}}(97.4 \%)$ and Marinobacter salicampi ISL- $40^{\mathrm{T}}$ (95.7\%). Levels of $16 \mathrm{~S}$ rRNA gene similarity between strain $20041^{\mathrm{T}}$ and other strains used in the phylogenetic analysis were less than $96.1 \%$. Similar tree topologies were found in the tree generated with the maximum-parsimony algorithm (data not shown).

The cell morphology of strain $20041^{\mathrm{T}}$ was examined with an Axioplan 2 microscope while colony morphology was observed on $\mathrm{MA}$ after incubation at $16{ }^{\circ} \mathrm{C}$. Growth temperature was determined with a TN3F temperaturegradient incubator (Advantec). The $\mathrm{pH}$ range for growth was determined for the strain in $\mathrm{MB}$ at various $\mathrm{pH}$ values adjusted with $1 \mathrm{M} \mathrm{HCl}$ or $1 \mathrm{M} \mathrm{NaOH}$. General physiological tests were performed using conventional methods (Dong \& Cai, 2001). Acid production from carbohydrates was determined as described by Leifson (1963). Biochemical traits were determined using API kits (API 20 E, API 20 NE, API ZYM; bioMérieux) according to the manufacturer's instructions, except that the cultures were suspended in $3 \%(\mathrm{w} / \mathrm{v}) \mathrm{NaCl}$ solution. Cells of strain $20041^{\mathrm{T}}$ were rod-shaped, Gram-negative and motile. Colonies were smooth, circular and convex with entire margins, at first white and later becoming pink on MA. Strain $20041^{\mathrm{T}}$ grew aerobically, the optimal growth temperature was $16-18{ }^{\circ} \mathrm{C}$, and growth occurred at $0-22{ }^{\circ} \mathrm{C}$. Furthermore, it could tolerate up to $8 \%(\mathrm{w} / \mathrm{v})$
$\mathrm{NaCl}$ but could not grow in the absence of $\mathrm{NaCl}$, indicating that it is halophilic.

Isoprenoid quinones were analysed as described previously (Komagata \& Suzuki, 1987) using reversed-phase HPLC, with ubiquinone-9 (Q9) from Marinobacter maritimus CK $47^{\mathrm{T}}$ as a reference standard. For fatty acid methyl ester analysis, cell mass of strain $20041^{\mathrm{T}}$ was harvested from MA plates following incubation at $16{ }^{\circ} \mathrm{C}$ for 5 days. The fatty acid methyl esters were extracted and prepared according to the standard protocol of the MIDI (Microbial Identification) system (Sasser, 1990). Cells of strain $20041^{\mathrm{T}}$ contained Q9 as the major respiratory quinone. The predominant cellular fatty acids of strain $20041^{\mathrm{T}}$ were iso- $\mathrm{C}_{15: 0} 2 \mathrm{OH}$ and/or $\mathrm{C}_{16: 1} \omega 7 c(22.16 \%), \mathrm{C}_{16: 0}$ $(13.98 \%), \mathrm{C}_{18: 1} \omega 9 \mathrm{c}(13.36 \%), \mathrm{C}_{12: 0} \quad 3 \mathrm{OH} \quad(10.17 \%)$, $\mathrm{C}_{16: 1} \omega 9 c(8.75 \%), \mathrm{C}_{17: 1} \omega 8 c(8.56 \%), \mathrm{C}_{17: 0}(7.76 \%)$ and $\mathrm{C}_{12: 0}(4.39 \%)$. The fatty acid profiles resembled those determined for recognized Marinobacter species (Romanenko et al., 2005; Shivaji et al., 2005; Yoon et al., 2007). The fatty acid profiles of strain $20041^{\mathrm{T}}$ and recognized Marinobacter species are available as supplementary material in IJSEM Online.

DNA base composition was determined by thermal denaturation $\left(T_{\mathrm{m}}\right)$ with Escherichia coli $\mathrm{K}-12$ as the reference. DNA-DNA hybridizations of strain $20041^{\mathrm{T}}$ to the type strain of Marinobacter maritimus were performed by thermal denaturation and the renaturation method of De Ley et al. (1970) as modified by Huß et al. (1983). The DNA G + C content of strain $20041^{\mathrm{T}}$ was $55.4 \mathrm{~mol} \%$. The DNA-DNA relatedness between strain $20041^{\mathrm{T}}$ and $M$. maritimus $\mathrm{CK} 47^{\mathrm{T}}$ was $32.7 \%$.

Strain $20041^{\mathrm{T}}$ was distinguishable from recognized Marinobacter species by several phenotypic characteristics

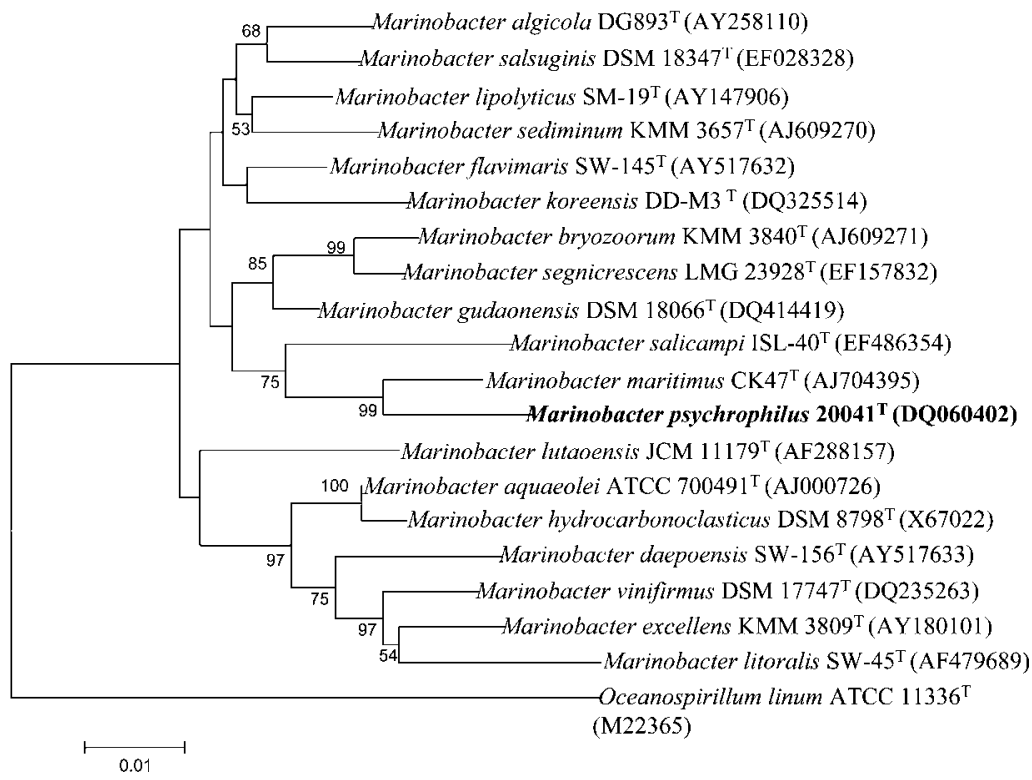

Fig. 1. Phylogenetic relationship of strain $20041^{\top}$ and recognized members of the genus Marinobacter based on 16S rRNA gene similarity. The tree was constructed using the neighbour-joining method. Numbers at nodes represent levels of bootstrap support (\%) based on a neighbour-joining analysis of 1000 resampled datasets. Oceanospirillum linum ATCC $11336^{\top}$ was used as an outgroup. GenBank accession numbers of $16 \mathrm{~S}$ rRNA sequences are given in parentheses. Bar, $1 \%$ sequence divergence. 
(Table 1). On the basis of the phenotypic, genotypic and phylogenetic data, it is proposed that strain $20041^{\mathrm{T}}$ represents a novel species of the genus Marinobacter, for which the name Marinobacter psychrophilus sp. nov. is proposed.

\section{Description of Marinobacter psychrophilus sp. nov.}

Marinobacter psychrophilus (psy.chro'phil.us. Gr. adj. psychros cold; Gr. adj. philos loving; N.L. masc. adj. psychrophilus cold loving).

Cells are Gram-negative, rod-shaped, psychrophilic and motile, with a size of $0.3-0.4 \mu \mathrm{m} \times 1.0-2.5 \mu \mathrm{m}$. Colonies are white in young cultures and can be pink with age, smooth, circular and convex with entire margins. Grows aerobically and produces catalase and cytochrome oxidase. Growth occurs at $0-22{ }^{\circ} \mathrm{C}$ and $\mathrm{pH}$ 5.0-10.0, with optimum growth at $16-18{ }^{\circ} \mathrm{C}$ and approximately $\mathrm{pH}$ 6.0-9.0. Growth occurs in the presence of $2-8 \%(\mathrm{w} / \mathrm{v}) \mathrm{NaCl}$ and no growth occurs in the absence of $\mathrm{NaCl}$. Nitrate is reduced to nitrite. Indole production and Voges-Proskauer are negative. Hydrogen sulfide is not produced. Arginine dihydrolase, lysine decarboxylase, ornithine decarboxylase, urease, gelatinase, trypsin, caseinase, agarase, chitinase, amylase, lecithinase, citrate utilization, acid phosphatase, $\alpha$-galactosidase, $\beta$ galactosidase, $\beta$-glucuronidase, $\beta$-glucosidase, $\alpha$-glucosidase, $\alpha$-chymotrypsin, $\alpha$-mannosidase, $\alpha$-fucosidase and naphtholAS-BI-phosphohydrolase are negative. Weak enzymic activity is observed for lipase (C14) and cystine arylamidase. Tests for esterase (C4), esterase lipase (C8), alkaline phosphatase, leucine arylamidase, valine arylamidase and $N$-acetyl- $\beta$ glucosaminidase are positive. Acid is produced only from glycerol. The following compounds are utilized as sole carbon and energy sources: D-arabinose, glycerol, sucrose and Dserine. The following compounds are not utilized as sole carbon and energy sources: dextrin, lactose, galactose, Dmannose, mannitol, xylose, L-rhamnose, melibiose, erythritol, raffinose, D-sorbitol, sorbinose, melezitose, ribose, trehalose, L-threonine, L-leucine, L-aspartic acid, L-glutamic acid, Lhistidine, $\mathrm{N}$-acetylglucosamine, trisodium citrate, capric acid, adipic acid and phenylacetic acid. The predominant cellular fatty acids of strain $20041^{\mathrm{T}}$ are iso- $\mathrm{C}_{15: 0} 2 \mathrm{OH}$ and/or $\mathrm{C}_{16: 1} \omega 7 c$ (22.16\%), $\mathrm{C}_{16: 0}$ (13.98\%), $\mathrm{C}_{18: 1} \omega 9 c(13.36 \%)$, $\mathrm{C}_{12: 0} 3 \mathrm{OH}(10.17 \%), \mathrm{C}_{16: 1} \omega 9 c(8.75 \%), \mathrm{C}_{17: 1} \omega 8 c(8.56 \%)$, $\mathrm{C}_{17: 0}(7.76 \%), \mathrm{C}_{12: 0}(4.39 \%), \mathrm{C}_{16: 1} \omega 5 c(1.72 \%), \mathrm{C}_{18: 1} \omega 7 c$ $(1.62 \%), \mathrm{C}_{11: 0} 3 \mathrm{OH}(1.36 \%), \mathrm{C}_{18: 0}(1.18 \%)$ and $\mathrm{C}_{15: 0}$ (1.21\%). Q9 is the principal isoprenoid quinone. The $\mathrm{G}+\mathrm{C}$ content of DNA is $55.4 \mathrm{~mol} \%$.

The type strain, $20041^{\mathrm{T}} \quad\left(=\mathrm{CGMCC} \quad 1.6499^{\mathrm{T}}=\mathrm{JCM}\right.$ $\left.14643^{\mathrm{T}}\right)$, was collected from the Canadian Basin $\left(78^{\circ} 23^{\prime}\right.$ $14^{\prime \prime} \mathrm{N} 149^{\circ} 06^{\prime} 55^{\prime \prime} \mathrm{W}$ ) in the Arctic.

\section{Acknowledgements}

This work was supported by the National Natural Science Foundation of China (30500001) and the National Basic Research Program of China (2004CB719601).

Table 1. Phenotypic characteristics that differentiate strain $20041^{\top}$ from related Marinobacter species

Species: 1, 20041 ${ }^{\mathrm{T}} ;$ 2, Marinobacter maritimus (Shivaji et al., 2005); 3, Marinobacter salicampi (Yoon et al., 2007); 4, Marinobacter segnicrescens (Guo et al., 2007); 5, Marinobacter bryozoorum (Romanenko et al., 2005); 6, Marinobacter gudaonensis (Gu et al., 2007). +, Positive; -, negative; w, weakly positive; ND, no data available.

\begin{tabular}{|c|c|c|c|c|c|c|}
\hline Characteristic & 1 & 2 & 3 & 4 & 5 & 6 \\
\hline \multicolumn{7}{|c|}{ Growth temperature $\left({ }^{\circ} \mathrm{C}\right)$} \\
\hline Maximum & 22 & 37 & 39 & 45 & 42 & 45 \\
\hline $\mathrm{NaCl}$ tolerance $(\%)$ & 8 & 13 & 15 & 15 & 18 & 15 \\
\hline \multicolumn{7}{|l|}{ Hydrolysis of: } \\
\hline Tween 80 & - & + & + & + & - & + \\
\hline Urea & - & + & - & - & - & - \\
\hline \multicolumn{7}{|l|}{ Utilization of: } \\
\hline Alanine & - & + & $\mathrm{ND}$ & - & - & + \\
\hline Mannitol & - & + & ND & - & - & - \\
\hline Fructose & - & + & - & $\mathrm{w}$ & - & + \\
\hline Xylose & - & + & - & ND & ND & $\mathrm{ND}$ \\
\hline $\begin{array}{l}\text { DNA G + C content } \\
(\mathrm{mol} \%)\end{array}$ & 55.4 & 58.0 & 58.1 & 62.2 & 59.6 & 57.9 \\
\hline
\end{tabular}




\section{References}

Antunes, A., França, L., Rainey, F. A., Huber, R., Nobre, M. F., Edwards, K. J. \& da Costa, M. S. (2007). Marinobacter salsuginis sp. nov., isolated from the brine-seawater interface of the Shaban Deep, Red Sea. Int J Syst Evol Microbiol 57, 1035-1040.

De Ley, J., Cattoir, H. \& Reynaerts, A. (1970). The quantitative measurement of DNA hybridization from renaturation rates. Eur $J$ Biochem 12, 133-142.

Dong, X.-Z. \& Cai, M.-Y. (editors) (2001). Determination of biochemical properties. In Manual for the Systematic Identification of General Bacteria, pp. 370-398. Beijing: Science Press (in Chinese).

Gauthier, M. J., Lafay, B., Christen, R., Fernandez, L., Acquaviva, M., Bonin, P. \& Bertrand, J.-C. (1992). Marinobacter hydrocarbonoclasticus gen. nov., sp. nov., a new, extremely halotolerant, hydrocarbondegrading marine bacterium. Int J Syst Bacteriol 42, 568-576.

Green, D. H., Bowman, J. P., Smith, E. A., Gutierrez, T. \& Bolch, C. J. S. (2006). Marinobacter algicola sp. nov., isolated from laboratory cultures of paralytic shellfish toxin-producing dinoflagellates. Int $J$ Syst Evol Microbiol 56, 523-527.

Gu, J., Cai, H., Yu, S.-L., Qu, R., Yin, B., Guo, Y.-F., Zhao, J.-Y. \& Wu, X.-L. (2007). Marinobacter gudaonensis sp. nov., isolated from an oilpolluted saline soil in a Chinese oilfield. Int J Syst Evol Microbiol 57, 250-254.

Guo, B., Gu, J., Ye, Y.-G., Tang, Y.-Q., Kida, K. \& Wu, X.-L. (2007). Marinobacter segnicrescens sp. nov., a moderate halophile isolated from benthic sediment of the South China Sea. Int J Syst Evol Microbiol 57, 1970-1974.

Huß, V. A. R., Festl, H. \& Schleifer, K.-H. (1983). Studies on the spectrometric determination of DNA hybridization from renaturation rates. Syst Appl Microbiol 4, 184-192.

Kim, B.-Y., Weon, H.-Y., Yoo, S.-H., Kim, J.-S., Kwon, S.-W., Stackebrandt, E. \& Go, S.-J. (2006). Marinobacter koreensis sp. nov., isolated from sea sand in Korea. Int J Syst Evol Microbiol 56, 2653-2656.

Komagata, K. \& Suzuki, K. (1987). Lipid and cell-wall analysis in bacterial systematics. Methods Microbiol 19, 161-207.

Kumar, S., Tamura, K. \& Nei, M. (2004). MEGA3: Integrated software for Molecular Evolutionary Genetics Analysis and sequence alignment. Brief Bioinform 5, 150-163.

Leifson, E. (1963). Determination of carbohydrate metabolism of marine bacteria. J Bacteriol 85, 1183-1184.

Liebgott, P.-P., Casalot, L., Paillard, S., Lorquin, J. \& Labat, M. (2006). Marinobacter vinifirmus sp. nov., a moderately halophilic bacterium isolated from a wine-barrel-decalcification wastewater. Int J Syst Evol Microbiol 56, 2511-2516.

Romanenko, L. A., Schumann, P., Rohde, M., Zhukova, N. V., Mikhailov, V. V. \& Stackebrandt, E. (2005). Marinobacter bryozoorum sp. nov. and Marinobacter sediminum sp. nov., novel bacteria from the marine environment. Int J Syst Evol Microbiol 55, 143-148.

Sambrook, J., Frisch, E. F. \& Maniatis, T. (1989). Molecular Cloning: $a$ Laboratory Manual, 2nd edn. Cold Spring Harbor, NY: Cold Spring Harbor Laboratory.

Sasser, M. (1990). Identification of Bacteria by Gas Chromatography of Cellular Fatty Acids. Technical Note 101. Newark, DE: MIDI.

Shivaji, S., Gupta, P., Chaturvedi, P., Suresh, K. \& Delille, D. (2005). Marinobacter maritimus sp. nov., a psychrotolerant strain isolated from sea water off the subantarctic Kerguelen islands. Int J Syst Evol Microbiol 55, 1453-1456.

Yoon, J.-H., Lee, M.-H., Kang, S.-J. \& Oh, T.-K. (2007). Marinobacter salicampi sp. nov., isolated from a marine solar saltern in Korea. Int $J$ Syst Evol Microbiol 57, 2102-2105.

Zhang, D.-C., Yu, Y., Chen, B., Wang, H.-X., Liu, H.-C., Dong, X.-Z. \& Zhou, P.-J. (2006). Glaciecola psychrophila sp. nov., a novel psychrophilic bacterium isolated from the Arctic. Int J Syst Evol Microbiol 56, 2867-2869. 